\title{
Ownership Structure, Corporate Governance and Capital Structure of Non-Financial Firms of Pakistan
}

\author{
Hassan Ahmad ${ }^{1 *}$, Nasreen Akhter ${ }^{1,2}$, Tariq Siddiq ${ }^{1}$, Zahid Iqbal ${ }^{3}$ \\ ${ }^{1}$ Dongbei University of Finance \& Economics, Dalian, China \\ ${ }^{2}$ Bahauddin Zakariya University, Multan, Pakistan \\ ${ }^{3}$ The Islamia University of Bahawalpur, Bahawalnagar Campus, Pakistan \\ hassaan1214@hotmail.com*, n_zahra786@hotmail.com, tariqsiddiq13@gmail.com, \\ zahid_luck2111@yahoo.com
}

\begin{abstract}
This study is undertaken with the purpose of investigating the impact of ownership structure and corporate governance on the capital structure of Pakistani listed firms from 2011-2014, feasible general least square is used to investigate the impact of ownership structure and corporate governance on capital structure of KSE 100 index firms. Explanatory variables include ownership concentration, managerial ownership, foreign ownership, institutional ownership, board size, board independence and CEO duality along with the three control variables namely firm size, firm profitability and liquidity. There is insignificant positive relationship between ownership concentration and capital structure, managerial ownership has a significant negative impact on debt ratio. Foreign ownership has also a significant negative impact on firm capital structure and institutional ownership has significant positive impact on capital structure. Board size is positively related to capital structure, board independence also positively related to firm's debt ratio but CEO duality negatively related to the dependent variable, all these variables have significant impact on capital structure of Pakistani firms.
\end{abstract}

Keywords: Ownership Structure, Corporate Governance, Capital Structure, Agency Theory, FGLS

\section{Introduction}

Capital structure based on two factor including debt and equity and same is given in the balance sheet of companies. Right or claim on companies' assets by the outsider is referred as debt portion of capital structure whereas right or claim on companies' assets by the owner of companies is referred as capital portion of capital structure. Current debt and long term debts are two important factor of capital structure. Financial soundness of company associated with the higher portion of owner equity in given capital structure. Issuance of long term debts and short term debts in a capital structure depends upon the company financial strategy. Common stock, preferred stock, undistributed profit and retain earning are the important element of owner equity. Common stock holder considered the real owner of company due to voting right as they are not received fixed rate of dividend, whereas preferred stock holder are not the real owner as they required fixed rate of dividend as compare to common stockholder. Capital theory was first familiarizing by the Modigliani and Miller in 1958. Lot of work has been done on capital theory by the many researchers but only few researchers focused to find out relationship between capital structure and corporate governance. Researcher also presents non-tax based theories including signaling theory, transaction cost and pecking order theories. The basic purpose of constructing capital structure is the maximization of shareholder wealth by reducing the cost of capital. Individual shareholders rights and collective interest of shareholders can be protected through corporate governance and by solving the all outstanding matters. Trustworthy relationship between shareholders, investor and lender can be created through good corporate governance. Continuous growth at organization level and country level associated with corporate governance.

In corporate governance role of manager is very important as he hire, fire and take key decision regarding business operations. The important contents and elements of corporate governance including sharing information with shareholders, board of director, senior management and reducing the conflict of interest between management and shareholders who played key role to make the structure of firm. Corporate governance can be ensured by maximizing the shareholder wealth and reducing the agency cost. According to Shleifer and Vishny (1997) assurance to the shareholder that they will get return on their investment is referred as corporate governance. The problems and epidemic of agency cost can be reduce through good corporate governance practice. The key stakeholder of corporate governance including managers, shareholders and board of directors. Financial opportunity can be gained and ensured through corporate governance as the corporate governance is the base for getting finance from outsider. Absence of corporate 
governance leads to agency cost in which management protect their own interest and rights instead of shareholders interest and right. Corporate governance has much more importance and important research are for financial school of thoughts. According to the Cadbury Report (1992) through corporate governance rights and interest of shareholders can be protected, directed and controlled. Corporate governance contains the right and responsibilities of shareholder, management and board of directors. Rights and interest of minority shareholder can be protected through better practices of corporate governance so that large shareholders may not expropriate the wealth of minority shareholders. Therefore, it is much important for companies who are working in Pakistan to comply with the corporate governance practices. Trustworthy relationship between all the stakeholder including managers, shareholders, employees and creditors can be built through corporate governance. Corporate governance first introduced by the Berl and Means.

In 1998 finally UK issued a Combined Code of Corporate Governance which was enforced on all the listed companies in the country. In reaction to these Massive bankruptcies and corporate debacles corporate governance laws and codes were developed is a series like Cadbury Report (1992), Greenbury Report (1995), Hampel Report (1998), The combined Code (1998), Turnbull Report (1999) of UK, Blue Ribbon Committee of NYSE (1999) of USA, Principles of Corporate Governance(OECD, 1999), Basle Committee Guidelines (1999), Muners Report (2001,UK), According to Revised Combined Code UK (2003) internal corporate governance structure and external corporate governance structure is weak as compared to other developed and underdeveloped countries. Different international bodies including the WB, the Global Corporate Governance Forum, International Monetary Fund (IMF) and International Corporate Governance Network also provide some instructions and guidelines regarding better practice corporate governance. Breakable internal and external corporate governance practices exist in Pakistan as compared to developed countries and developing countries. But now in Pakistan corporations and companies swiftly adopting the rules and practices of corporate governance. Govt. of Pakistan adopting and showing keen interest in corporate governance as revenue of Government depends upon the better practice of corporate governance. Different international organization including Finance Corporation and World Bank fixed strong check and balance and published different reports regularly on corporate governance. Security \& Exchange Commission of Pakistan (SECP) take first step to ensure the practice governance practices by issuing the corporate governance codes in March 28 ${ }^{\text {th }}, 2002$. Corporate governance code issued by the Security \& Exchange Commission of Pakistan (SECP) is based on international accepted principles including transparency, openness and accountability in the affairs of companies.

According to the principles of corporate governance all companies who are listed on Pakistan Stock Exchange (PSE) are required to publish their financial reports as per rules and regulations of corporate governance. Different national organization includes Institute of Chartered Accountant of Pakistan (ICAP) and Pakistan Institute of Corporate Governance (PICG) also working to protect the rights of all stakeholders by highlighting the importance of corporate governance. Besides these organization Security \& Exchange Commission of Pakistan (SECP) and State Bank of Pakistan (SBP) also working to implement the rules and practices of corporate governance. For different financial school of thoughts corporate governance and ownership structure is embryonic concept. Different variable including corporate governance, dividend policy, capital structure and firm value used by different researchers in their research study. According to the latest research most of research work done to investigate the impact of corporate governance on financial performance of companies and to find out the relationship between capital structure and corporate governance. Now the relationship between capital structure and corporate governance has not been fully reconnoitered. Arslan \& Zaman (2014), Masood \& Shah (2014) and Ahmed \& Wang (2012) conducted different study to observe the relationship between capital structure and corporate governance, whereas no research was conducted in Pakistan to check the impact of both ownership structure and corporate governance of capital structure in Pakistan.

\section{Literature Review}

As steered by Modigliani \& Miller (1958) different theories including pecking order theory, trade off theory and agency theory were introduced and used on different research study regarding capital structure in both developed and developing countries. According to these theories different companies have different choices of capital structure (Lingling, 2013). The details regarding different capital theories are given as under. 
Theoretical Background: Common Stock Shareholders are the real owner of companies and management recruited to ensure and protect the rights of shareholder by increasing the shareholder wealth not the maximization the wealth of management. Shareholder also faced some cost to resolve the problems regarding agency problems are referred as agency cost. Management used more debts to increase the profit but return against these debts must be used to pay the interest on debts and principal amount. Debt also used by the different companies to mitigate the agency cost as well. Shareholders also take risk by making investment in risky project to earn high return but the decision of shareholder to make investment in risky project damaging the interest of debt holders or lender. But firm can only pay the principal amount and interest on debt by making investment in more risk project as return on risky project is high as compared to less risky project. Large shareholders also maximize their wealth by expropriating the minority shareholders rights (Shleifer and Vishny, 1997). Normally debt financing is considered better and favorable by the shareholders. If a firm used debt financing it indicates that firm has strong financial position but the management does not intend to share the major portion of profits between the shareholders (Ryen et al, 1997: Koch and Shenoy, 1999). If a firm issues debt it also indicates and give message to the market that this time shareholder of that specific companies will receive dividend.

Debt ratios of each firm vary from other firm as every firm capital structure different from each other. Firm used optimal capital structure by tradeoff the benefits of tax saving and interest on debts (Myers, 2001). Whereas high debt ratio also leads to bankruptcy but high tax benefits and low debt ration less chances of bankruptcy at the cost of high tax. Manager of the firms are well informed about the financial affairs and financial position of companies as compare to the investors and other stakeholders. It is not possible for external investor to access the actual performance and future value of firm. Making investment by using the retain earning this problem can be solved. If external financing become unavoidable then the firm fulfills its capital requirement though debt financing first by issuing debt securities and then move to the equity financing by issuing of shares. It means external financing is not required by the firm in case of high profit but in case of low profit firm must go for external financing by issuing debt securities because no retain earning available in case of low profit (Ahmad Ahmadpour et al, 2012). This theory suggests that firm move from internal financing to external financing or in other words in case of high profits internal financing should be used and in case of low profit external financing should be preferred.

Ownership structure: Amendments in company, director election and modifications in company status, appointment of auditors and approval of extraordinary transactions are the important matters on which shareholder has full command and influence. As mentioned by Abel and Okafor (2010) ownership structure is the ratio of shares held by Manager (Managerial ownership), institutions (Institutional ownership), government (State ownership), foreign investors (Foreign ownership) etc. As steered by Jensen \& Mackling (1976) ownership structure the combination of shares held by manager, debt and equity holder. Al-Najjar and Taylor (2008) investigated the relationship between capital structure and ownership structure. According to them firm size and risk in business depends upon the capital structure and ownership structure.

Capital Structure: Maximization of shareholder wealth and reduction in cost of capital depends upon the optimal capital structure. Agency cost incurred or increase as we include more debts in our capital structure. As steered by Myers (2001) firm can gain maximum tax benefits by using more debts in capital structure and getting more profit that ultimately leads to maximization of shareholder wealth. According to 0 , Connel and Cramer (2010) positive and significant relationship was observed between firm leverage and firm value in their study. They also added that firm debts positively contribute to the firm performance by increasing the shareholder wealth. According to them market performance can be increased by using the more debts. As mentioned by Saeedi and Mahmoodi (2011) optimal capital structure has positive impact on firm performance and increase the firm vale as well by maximizing the shareholder wealth. According to the study of Salim and Yadav (2012) positive and significant association was found between capital structure and Tobin Q. As per study of Bender (2013) life of firm and firm value depends upon the capital structure. According to him financial risk depends upon the financing needs of firm. He mentioned that as financial risk enhance it leads to moderate risk during the firm life.

Relationship between Ownership structure and Capital structure: Voting rights in firm depends upon the number of shares held by a specific person or ownership structure. Since last few years much importance has 
been gotten by the ownership structure and capital structure. Owner equity and outsider equity are the two important factor or elements of ownership structure (Jensen and Meckling, 976). Zheka (2005) conducted a study by taking the multiple variable including $\%$ of managerial ownership, large institutional ownership and government ownership to observe the association between ownership structure and capital structure. A Bajaj et al (1998) remark that there is a positive and significant relationship was found between debt to equity ratio and ownership structure. Friend and Lang (1988) conducted a study and suggested negative correlation among managerial ownership and debt to equity ratio. Mishra and McConaughy (1999) steered that in case of family firm there is less need of financing as compare to the non-family controlled and managed firms. As mentioned by Anderson and Reeb (2003) in case of family firm less financing cost was observed. Berger et al (1997) mentioned that less debt financing is required if no major stakeholder exist in firm ownership structure. According to Cheng et al (2005) there is positive association was found among ownership concentration and leverage. In his study Driffield et al (2005) both in family owner firm and non-family owned firm a significant and positive association was found among leverage and ownership concentration in various studies especially regarding developing countries extensive relationship was observed between capital structure and ownership structure. According them capital structure and ownership structure positively correlated and interrelated with each-others. Masood \& Shah (2014) suggested and discussed the importance of capital structure and its impact on ownership structure. According to survival, growth and stability of firm depends on ownership structure and capital structure and these both factor positively contribute to the firm performance.

Relationship between Ownership Concentration and Capital Structure: Block holder's shareholder is those shareholders that have more than 5\% shares of the firms. In their study Friend \& Lang (1988) stress that company will used more debts if a firm have more major shareholder and used less debts if a firm have less major shareholders. They also suggested positive and significant relationship between concentration and leverage. Driffield et al (2005) suggested that as ownership concentration increase as leverage increases and vice versa. Zeituni and Tain (2007) argued that ownership concentration has positive impact on the firm value and firm performance. In his study he found positive relationship between ownership structure and firm performance, whereas negative relationship between capital structure and firm performance in 5 GCC countries including Qater, Kuwait, Saudi Arabia, Bahrain and Oman. Masood \& Shah (2014) conducted a research in developing countries like Pakistan by taking the manufacturing firms as sample study to observe the relationship between ownership structure and capital structure. In this study Harfindhal index was taken as research methodology to observe the relationship between ownership concentration and capital structure. According to the finding of the study negative and significant relationship was observed between ownership concentration and capital structure. $s$

\section{$\mathrm{H}_{1}$ : All else being equal, ownership concentration is positively related to capital structure}

Relationship between Managerial ownership and capital structure: Hostile takeover can be eliminated by using more debt financing than the equity financing by the managers of various firms Pindado \& La. Torre, 2011). As steered by Mohid et al (1998) most of the firms who intend to increase to increase the performance of their managers used debt financing as the debt financing reduce the agency cost. Most of manager successfully reduces the risk of business through the effective ownership (Huang \& Song, 2006). Mostly managers used debt financing to minimize the agency cost and to increase the voting rights of managers and to enhance the control over the firms. According to the research conducted by Brailsfor (2002) there is nonlinear association and link was observed between capital structure and ownership structure. In this study negative relationship by keeping in view the agency cost and taxes institutional owner make a mix of capital structure is called optimal capital structure. To increase the public and supplier interest in company agency cost can be reduced. Institutional investor has greater control over the firm due to great interest in company and due to this they have vital roles in capital structure adjustment. Debt tendency will be lower if a firm have more institutional investors. According to Grier and Zychowicz (1994) they found no relationship between institutional ownership and capital structure as the sample of their study consists of family representatives companies. Bodaghi and Ahmadpour (2010) suggested that according to the corporate governance theory and principles there is a positive and significant relationship was observed between institutional ownership and capital structure. Arshad and Safdar (2009) mentioned that debt to equity ratio have significant impact on capital structure in Pakistan, also found between managerial ownership and capital structure. According 
to the results of this study agency problems can be eliminated and reducing through managerial ownership. Most of manager eliminating or minimize the bankruptcy cost by using more debts in their capital structure. $\mathrm{H}_{2}$ : All else being equal Managerial ownership is Negatively related to capital structure

Relationship between Institutional ownership and Capital Structure: short et al. (2002) examine the influence of ownership structure on the financial structure of UK firms. Their results revealed that there exists positive relationship between management ownership and leverage ratio whereas negative relationship was observed between large external equity holder's ownership and financial leverage. The study of Masood \& Shah (2014) in Pakistan checked the association among institutional shareholding and capital structure of the firms listed at KSE. Short et al. (2002) observed that ownership structure has significant relationship with financial structure in UK. The results of the study indicate that significant and positive relationship was observed among management ownership and leverage ratio whereas inverse relationship was accessed between external equity holder ownership and financial leverage. Masood \& Shah (2014) stress that there is a significant association was observed between institutional shareholder and capital structure among the firms that are listed at Pakistan Stock Exchange (PSE). According to the study conducted by taking the 121 firms as sample study an inverse relationship was observed between institutional investors and capital structure. So the hypothesis that there is a significant association between institutional ownership and capital structure is rejected. According to Akbari \& Rahmani (2013) external debts was arranged by the institutional shareholder under favorable terms.

$\mathrm{H}_{3}$ : All else being equal, Institutional ownership is positively related to capital structure

Relationship between Foreign ownership and capital structure: When a person of foreign country invests in specific company that ownership of investment is referred as foreign ownership. Holding company is that takes the more than $50 \%$ of shares whereas a company that surrounded more than $50 \%$ of its shares is called target company. Bokpin et al. (2009) added that capital structure and foreign ownership has significant and positive relation with each other. Performance of firms can be enhanced through foreign ownership and corporate governance increase as foreign ownership increase. In this study foreign ownership is referred as percentage of ownership by the foreign individual, investor or companies. In some other studies like Svejnar \& Kocenda (2002), Li et al. (2009) and Lee and Kwok (1988) observed negative relationship between foreign ownership and capital structure. According to Mieno (2009) and Gurunlu \& Gursoy (2010) low gearing level was observed with high foreign investment because most companies whose capital mainly depends upon foreign investment have high level of retained earnings to finance their projects. Gedajlovic et al. (2005) like the earlier studies results found significant and negative association between foreign ownership and capital structure. Tamimi (2011) in his study also noted inverse relationship between capital structure and foreign ownership.

$\mathrm{H}_{4}$ : All else being equal, foreign ownership is positively related to capital structure

Relationship between Corporate Governance and Capital Structure: Corporate governance can play an important and vital role to enhance the investor interest in specific companies by enhancing the performance of companies. Capital structure of the firms can be determined accessed through the positive contribution and important role of corporate governance. According to her corporate governance plays an important role between the firm's level of leverage and firm value. She further added that corporate governance and capital structure and firm value have significant and positive relationship. According to the findings of this study significant and positive relationship among the capital structure and value of the firms was observed. In this study they added that corporate governance practices can be increased through independence ownership concentration as the positive and significant relationship between ownership concentration and firm value was observed in this study. Ukaegbu (2014) conducted a study to observe the relationship between corporate governance and capital structure and also observed its impact on firm value. For this study panned data of non-financial Nigerian firms was used. In this study with respect to short term leverage negative and inverse relationship was observed between capital structure and firms performance. In this study positive and significant relationship was observed between firm's performance, leverage, board meeting and board size.

Relationship between Board Size Capital Structure: According to the Pfeffer and Salancick (1978) mentioned that size of the board and capital structure have significant and positive relationship. In Pakistan the maximum board size was observed 19 members whereas the minimum board size was observed on 7 
members. Berger et al. (1997) added that large board size and gearing level negative correlated with each other. According to this study large board size leads to low debt level resulting positive performance of the firms. According to the Wen et al. (2002) positive relationship was observed between board size and capital structure. According to him firm's performance can be increase by enhancing the board size that resulting high gearing level also. In case of large board size debt cost will be lower due to strict check and balance due to more member of board. Mak \& Kusnadi (2005) observed significant and negative relationship between size of the board and value of the firms. Cheng (2008) added that discussion regarding board size and firm's performance is less important as in his study he did not found any relationship between size of board and firm performance. Adams \& Mehran (2012) conducted a study to make banks as sample to observe the firm's performance relationship with board size. In this study he observed that board size and firm performance has positive and significant relationship. Kumar and Singh (2013) conducted a same nature study on Indian firms he also observed positive and significant relationship between firm size and firm performance. Rajangan et al. (2014) concluded that significant and positive relationship was observed in Malaysian companies with reference to board size, ownership structure, firm performance and gearing level.

Independent director and executive director have positive influence on the financial performance of the firms and gearing level whereas negative relationship between firm's performance and leverage was observed in case of non-independent director and non-executive director. Coles et al. (2008) conducted a study on American firms and reported that there is significant and positive relationship observed between board size and capital structure in its impact on firm's financial performance. He further added that more legal advices are required in case of high gearing ratio and low legal services required in case of less gearing ratio. Anderson et al. (2004) observed significant and positive association between board size and debt ratio. He also added that in case of large board size firms can easily get finance at reasonable term and conditions as compare to the less member board size. According to Wen et al. (2002) better monitoring and check and balance can be ensured in case of large board size that resulting high gearing ratio that leads to superior performance of firms.

$\mathrm{H}_{5}$ : All else being equal, Board Size is positively related to capital structure

Relationship between CEO Duality and Capital Structure: Lam and Lee (2008) conducted a study to observe the relationship between CEO duality and firm performance. According to the findings of the study CEO duality have less importance in context of firm's performance in case of family control business whereas CEO duality have positive impact on financial performance in case of non-family firms. Fosberg (2004) observed significant and positive relationship between corporate governance, capital structure, CEO duality and gearing level. Abor (2007) also observed significant and positive association between dual leadership and capital structure.

\section{$\mathrm{H}_{6}$ : All else being equal, CEO duality is positively related to capital structure}

Relationship between Board independence and Capital structure: An outsider director is not allowed to participate in executive management of the company. Performance of the firms and interest of its stakeholders can be protected through the involvement of external directors because the external director take immediate measure and strong stand against each and every wrong decision. According to Jensen (1986) and Berger et al. (1997) mentioned firm's performance can be enhanced by increasing the number of external director. They also added that firm's debt level found minimized with the low number of external director. Abor \& Biekpe (2007) capital structure and chair duality in composition board are positively correlated with each other. They also added that with the involvement of outside director financial performance of firms can be enhanced by minimizing the debt level and debt cost. Erickson et al. (2005) in their study reported negative relationship between board independence and firm's financial performance. Motavassel et al. (2013) conducted a study to observe the relationship between outside director and firm value and reported negative relationship between observed variables. Ahmed and Wang (2012) conducted a study on non-financial firms that are listed in KSE by taking the data from 2004-2008. In this study they observed significant and positive relationship between observed variables including board size, outside director and capital structure.

$\mathrm{H}_{7}$ : All else being equal, Board Independence is positively related to capital structure 
Table 1: Literature Review

\begin{tabular}{|c|c|c|}
\hline Variable & $\begin{array}{l}\text { Relationship } \\
\text { With Leverage }\end{array}$ & Empirical Evidence \\
\hline \multirow{4}{*}{$\begin{array}{l}\text { Ownership } \\
\text { Concentration }\end{array}$} & Positive & $\begin{array}{l}\text { Brailsford, et al.(2002),Margaritis \&Psillaki(2010),Pindado\& La } \\
\text { Torre (2011), Céspedes, et al.(2010) }\end{array}$ \\
\hline & Negative & Short, et al. (2002), Liu, et al.(2011) \\
\hline & Non-Linear & La Bruslerie\&Latrous (2012), Shi (2010) \\
\hline & No Impact & Huang \&Song(2006) \\
\hline \multirow{3}{*}{$\begin{array}{l}\text { Managerial } \\
\text { Ownership }\end{array}$} & Positive & Mehran(1992), Berger, et al.(1997) and Short, et al. (2002) \\
\hline & Negative & $\begin{array}{l}\text { Jensen, et al. (1992), Bathala, et al. (1994),Firth(1995), Mohid, et } \\
\text { al.(1998), Chen \& Steiner(1999) }\end{array}$ \\
\hline & Non-Linear & Brailsford, et al.(2002) \\
\hline \multirow[b]{2}{*}{ Foreign Ownership } & Positive & Godfred A, et al. (2009) \\
\hline & Negative & $\begin{array}{l}\text { Svejnar, (2002) Li et al. (2009) Lee and kwok(1988) } \\
\text { Mieno(2009), Gurunlu and gusrsoy(2010), Gedajlovic et } \\
\text { al.(2005) and Tamimi(2011) }\end{array}$ \\
\hline \multirow{2}{*}{$\begin{array}{l}\text { Institutional } \\
\text { ownership }\end{array}$} & Positive & $\begin{array}{l}\text { Pushner (1995), Firth(1995)Deesomsak, et al.(2004), Driffield, et } \\
\text { al.(2007), González, et al.(2012), Akbari \&Rahmani(2013) }\end{array}$ \\
\hline & Negative & Schmid (2013) \\
\hline \multirow[b]{2}{*}{ Board Size } & Positive & Wen (2002) \\
\hline & Negative & $\begin{array}{l}\text { Berger (1997), Abor and Biekpe } \\
(2007)\end{array}$ \\
\hline \multirow[t]{2}{*}{ Board Independence } & Positive & $\begin{array}{l}\text { Pfeffer and Salancick (1978), Jensen (1986) and Berger et al } \\
(1997) \text {, Abor and Biekpe (2007) }\end{array}$ \\
\hline & Negative & Erickson et al. (2005), Wen (2002) \\
\hline \multirow[t]{2}{*}{ CEO Duality } & Positive & $\begin{array}{l}\text { Fosberg(2004), Faleye (2004), Abor (2007), Abor and Biekpe } \\
(2007), \text { Nazir et al (2012) }\end{array}$ \\
\hline & Negative & (Jensen \& Meckling, 1976; Fama \& Jensen, 1983) \\
\hline
\end{tabular}

\section{Methodology}

The core objective for writing this piece of research article is to observe the relationship between corporate governance and capital structure by taking 56 companies that are listed at KSE 100 index. In this study an effort has been made to observe the impact of ownership structure and corporate governance factor on capital structure. In this study secondary data was used that is collected from the annual reports of companies. For construction of strong building block to support the study both domestic and international studies used as basis. In this study local firm that are listed at Karachi Stock Exchange (KSE) 100 index was taken as sample size. Data from 2011 to 2014 was collected as the during this observed massive development in stock market was observed and concept of corporate governance also flourished and get importance in this period. For the purpose of data collection financial reports of observed companies were gotten from the website of respected companies. In these firms non-financial firms were taken as sample size because there is difference between financial firms and non-financial firms on the basis of their capital structure. The basis reason regarding taking the KSE-100 index companies is that because the performance of these companies is remarkable as compare to other companies and phenomena of corporate governance was adopted by these companies with letter and spirit as compare to the others companies. In this study observed companies was randomly selected by keeping in view the various factors including availability of data from 2011-2014 and availability of observed variables in the annual reports of the firms.

\section{The above mentioned details helped to reach the desired sample of this study which is shown below} as:

- KSE 100 index consist of 100 companies

- Out of 100 companies 24 are related to financial sector, 76 companies are related to none-financial sector 
- This study includes the four-year data of 56 firms out of 76 none financial firms, 20 firms are excluded due to the unavailability of data.

- So out of 304 observations of 76 firms this study includes 224 observations of 56 firms

Model Specification:

CapitalStructure $=\alpha+\beta 1$ CONC $+\beta 2$ MGOS $+\beta 3 F O S+\beta 4 I N S O S+\beta 5 B S I Z E+\beta 6 B I N D+\beta 7 C E O D+\beta 8 P R O F I T+\beta 9 F S I Z E+\beta 10 L$

$I Q D+\mu$

$\alpha=$ Represented Constant

BIND=Board Independence

$\beta=$ Beta Coefficients

CONC $=$ Ownership Concentration

MGOS= Managerial Ownership

FOS=Foreign Ownership

INSOS= Institutional Ownership

CEOD $=$ CEO Duality

PROFIT=Profitability

BSIZE $=$ Board Size

FSZIE=Firm size

LIQD= Liquidity

$\mu=$ Error Term

Table 2: definition of study variables

\begin{tabular}{|c|c|c|}
\hline Variables & Definition & Sources \\
\hline Leverage & Total debt to total assets & $\begin{array}{l}\text { (Wellalage and Locke, 2014) } \\
\text { (Masood \& Shah, 2014). }\end{array}$ \\
\hline $\begin{array}{l}\text { Ownership } \\
\text { Concentration }\end{array}$ & $\begin{array}{l}\text { The shareholders having } 5 \% \text { or more voting } \\
\text { interest in the company }\end{array}$ & $\begin{array}{l}\text { (Ahmad Ahmadpour et al, } \\
\text { 2012). }\end{array}$ \\
\hline $\begin{array}{l}\text { Managerial } \\
\text { Ownership }\end{array}$ & $\begin{array}{l}\text { The percentage of shares held by directors, } \\
\text { executives, spouses and children }\end{array}$ & (Bear et al, 2010). \\
\hline $\begin{array}{l}\text { Foreign } \\
\text { Ownership }\end{array}$ & $\begin{array}{l}\text { The percentage ownership of foreign investors, } \\
\text { individuals or companies }\end{array}$ & Tamimi (2011) \\
\hline $\begin{array}{l}\text { Institutional } \\
\text { Ownership }\end{array}$ & $\begin{array}{l}\text { The percentage of shares held by the institutions } \\
\text { disclosed in the annual report }\end{array}$ & (Hasan and Butt, 2009). \\
\hline Board Size & $\begin{array}{l}\text { Log of the total number of members of the board as } \\
\text { disclosed in annual report }\end{array}$ & $\begin{array}{l}\text { (Ahmad Ahmadpour et al, } \\
\text { 2012). }\end{array}$ \\
\hline CEO Duality & $\begin{array}{l}1 \text { is taken if CEO also chairs the board otherwise it } \\
\text { is taken as } 0\end{array}$ & Hasan and Butt, 2009). \\
\hline $\begin{array}{l}\text { Board } \\
\text { Independence }\end{array}$ & $\begin{array}{l}\text { The number of non-executive/independent } \\
\text { directors }\end{array}$ & Hasan and Butt, 2009). \\
\hline Profitability & EBIT to Total Assets & Hasan and Butt, 2009). \\
\hline Size of firm & Log of book assets & Hasan and Butt, 2009). \\
\hline Liquidity & Current Ratio & Lingling (2013) \\
\hline
\end{tabular}

Econometric Methodology: In this study panel data used to observe the impact of ownership structure and corporate governance on capital structure of Karachi Stock Exchange (KSE) listed companies. This segment of study reveals the methodology used to estimate the regression equation. In this panel data used as the data of different companies regarding different period involved in this study. The problems autocorrelation and Heteroscedasticity arises if we used simple OLS model to find out the relationship between observed variables. Variable biasness can be reduced by taking the panel data as the panel data overlooked the heteroscedasticity and expose the data dynamics due to high degree of freedom and low multicolinetary. Error of measurement can be reduced and issue of bigger amount can be solved by transforming the data. We have balanced panel and also have equal observation in all time periods. We can also remove the unobserved effect by summing it to disturbance term. If errors are correlated with $u$ than we must use the fixed effect model. But if the data has the issue of autocorrelation the generalized least square and feasible generalized least square can be used to overcome this problem in random effect model. We have to use that procedure of estimation that can better solve the above mention problems in different models. Ordinary least square can 
also be used in the case we have continuous coefficients with uniform residuals. OLS can also be used to estimate the Fixed-Effect model if the model does not bump into the Heteroscedasticity whether group wise of other effect on dependent variables. EGLS and FGLS work effectively where there exist Heteroscedasticity (Yafee). Therefore, we have the FGLS approach to estimate the model. FGLS permits estimation in the existence of AR(1) autocorrelation within panels and cross-sectional correlation and Heteroscedasticity across panels. GLS method gives us BLUE and asymptotically efficient estimates (it is based on variance component). Maddala \& Mount, (1973) compared OLS, FE, RE and MLE methods using Monte Carlo experiments. Their results did not prove any of them better than the other. If the observed variance is unequal or they have serial correlation, then the method of GLS is used to estimate unknown parameters (because OLS will give inefficient estimates). The GLS estimator is an OLS estimator of a transformed 'isomorphic' model (the generalized linear model). It provides the BLUE under Heteroscedasticity/ serial correlation. Generalized last squares (GLS) method is used for estimation of random effects when variance structure is known and if the variance structure is unknown then feasible generalized least squares is applied for estimation (FGLS).

\section{Results and Discussion}

Findings/Empirical Results: The aim of this study is to find the "The impact of ownership structure and corporate governance on capital structure of the KSE 100 index companies. Below mention table present the summary statistics for dependent and independent variable. Descriptive statistics like mean median mode mainly provide the location of data and the standard deviation provide the deviation of data from its mean.

Table 3: Descriptive Statistics

\begin{tabular}{llll}
\hline Variable & Observations & Mean & Standard Deviation \\
\hline Ownership Concentration & 224 & 63.1656 & 22.0977 \\
Managerial Ownership & 224 & 16.6100 & 22.4545 \\
Foreign Ownership & 224 & 15.6002 & 26.1409 \\
Institutional Ownership & 224 & 63.5165 & 29.5035 \\
Board Size & 224 & 0.9593 & 0.18242 \\
CEO Duality & 224 & 0.125 & 0.33146 \\
Board Independence & 224 & 6.04464 & 2.53191 \\
Firm Size & 224 & 7.81165 & 1.16134 \\
Profitability & 224 & 14.9643 & 10.3924 \\
Liquidity & 224 & 1.69725 & 1.17906 \\
Debt Ratio & 224 & 48.6821 & 22.2249 \\
\hline
\end{tabular}

Descriptive Statistics: The above mention table presents the mean and standard deviations of dependent and independent variables. Mean value of ownership concentration is 63.1656 and SD is 22.097 this means that in the sample companies an average $63.1656 \%$ of shareholdings are concentrated or hold by the largest block holders and $22.097 \%$ deviation from the mean. Mean value of managerial ownership 16.61, this means sample firms have an average about $16.61 \%$ holdings by the management of the company. 15.6002 is the mean value of foreign ownership this value depicts that average of $15.6 \%$ share are held by the foreign investors. Mean value of the institutional ownership is 63.5165 means that in the sample firms an average of $63.51 \%$ shares is held by the institutions both financial and none financial. This mean value 0.9593 shows the mean of the log of board size this value means that sample firms having average 9 directors on their board. This mean value shows the out of 100 CEO's $12.5 \%$ are also holding the chairmanship of the board. Board independence mean value is 6.044 this value shows that an average of 6 independent directors are present in the board. Mean value for firm size 7.81 this is the mean of log of firm's book assets. Mean of profitability shows a mean value of 14.96 this means that sample firms have a $14.96 \%$ return on assets. 1.69725 is the average of the current ratio means how much current assets are there to fulfill the short term obligations this value shows that firms are having 1.69 times current assets then their current liabilities. At 
the end the mean value of Debt Ratio is 48.6821 means that sample firms having an average about $48.68 \%$ of debt in their capital structure.

Generalized Least Square Results: This study uses GLS regression to estimate the model from a panel data because panel data contains the issues of autocorrelation and heteroskedasticity so GLS control these kinds of issues. We also use number of control variables to get robust results of pure independent variables.

GLS after Controlling GroupWise Heteroskedasticity and Auto Correlation

\begin{tabular}{|c|c|c|c|c|c|c|c|c|c|c|c|}
\hline & CONS & MGOS & FOS & INST & BSIZE & $\begin{array}{l}\text { CEO } \\
\text { Duality }\end{array}$ & BIND & FSIZE & PROFIT & LIQD & $\begin{array}{l}\text { Debt } \\
\text { Ratio }\end{array}$ \\
\hline Coefficient & 0.028 & -0.074 & -0.110 & 0.068 & 8.310 & -5.606 & 0.415 & 5.121 & -0.099 & -11.301 & 17.061 \\
\hline $\begin{array}{l}\text { Standard } \\
\text { Error }\end{array}$ & 0.0302 & 0.0343 & 0.0157 & 0.0223 & 3.2552 & 1.2031 & 0.20016 & 0.5226 & 0.0488 & 0.6353 & 5.7928 \\
\hline Z Value & 0.95 & -2.16 & -7.02 & 3.06 & 2.55 & -4.66 & 2.08 & 9.8 & -2.02 & -17.79 & 2.95 \\
\hline $\mathrm{P}>\mathrm{Z}$ & 0.344 & $0.031 *$ & $0.000^{* *}$ & $0.002^{* *}$ & $0.011^{* *}$ & $0.000^{* *}$ & $0.038 *$ & $0.000^{* *}$ & $0.044^{*}$ & $0.000^{* *}$ & $0.003^{* *}$ \\
\hline Wald Test & 1369.55 & 1369.55 & 1369.55 & 1369.55 & 1369.55 & 1369.55 & 1369.55 & 1369.55 & 1369.55 & 1369.55 & 1369.55 \\
\hline Prob> chi2 & 0.000 & 0.000 & 0.000 & 0.000 & 0.000 & 0.000 & 0.000 & 0.000 & 0.000 & 0.000 & 0.000 \\
\hline $\begin{array}{l}\text { Auto } \\
\text { correlation }\end{array}$ & 0 & 0 & 0 & 0 & 0 & 0 & 0 & 0 & 0 & 0 & 0 \\
\hline
\end{tabular}

Note: ${ }^{* *}$ and ${ }^{*}$ these signs P>z row denotes the significance levels. Note: ${ }^{*}$ this sign shows the significance level is $5 \%$ and ${ }^{* *}$ this shows the level of significance is $1 \%$.

The above table shows the STATA results of ownership structure corporate governance variables with respect to leverage. Ownership structure and corporate governance is independent variable and leverage is dependent variable. As shown is the above table;

- Ownership concentration is positively related to leverage as the coefficient is positive but statistically insignificant as $0.344>0.05$

- Managerial ownership is negatively related to leverage as the coefficient is negative but statistically significant as $0.031 *<0.05$

- Foreign ownership is negatively related to leverage as the coefficient is negative but statistically highly significant as $0.000^{* *}<0.05$

- Institutional ownership is Positively related to leverage as the coefficient is positive and statistically significant as $0.002^{* *}<0.05$

- Board size is positively related to the leverage as the coefficient is positive and also statistically significant as $0.011^{* *}<0.05$

- CEO Duality is negatively related to the leverage because the coefficient is negative and statistically highly significant as $0.000^{* *}<0.05$

- Board Independence is also positively related to the leverage as the coefficient is positive and statistically significant $0.038^{*}<0.05$

Note: *this sign shows the significance level is $5 \%$ and ${ }^{* *}$ this shows the level of significance is $1 \%$.

Theoretical Support from Previous Studies: This study examines the impact of ownership structure and corporate governance variables on leverage of KSE 100 index companies of Pakistan. The results of Generalized Least square have been presented in above mentioned tables. Discussion of above mention results and possible reason why there exist such relationship between independent and dependent variables. 
In this study, Ownership concentration is positively related to debt ratio and statistically insignificant. This finding suggests that higher the ownership concentration higher will be the debt ratio or leverage of the firm. But in Pakistan most of the companies have concentration of ownership (Cheema et al 2003). In Pakistani companies most of the shares of the companies are held by family members and their relatives, so that they prefer debt financing over equity due to fear of the dilution of ownership and control (Hasan \& Butt, 2009). Managerial ownership is negatively related to debt ratio and statistically significant. This finding suggests that it is similar to agency theory that managers put their goals ahead than the corporate goals. This leads to conflict of interest between management and the owners of the firm. The negative relation between managerial ownership and leverage means that management favors lower debt to be employed in the firm. Because higher the debt ratio higher the risk is imposed to the managers than the shareholders. If more debt is employed free cash flow is used to service these debts and less is available to the managers as bonuses and remuneration. Thus higher the managerial ownership lower will be the leverage of the firm. Brailsford et al. (2002) stated that there is nonlinear relationship exist in capital structure and managerial ownership. The author also found a negative relationship between managerial ownership and capital structure. He states that managerial ownership leads to reduced agency problems, managers tends to be highly concerned with the well-being of the company, therefore they use low level of debt to reduce the bankruptcy cost. The negative relationship between managerial ownership and capital structure is also found in Fosberg (2004), Friend and Lang (1988) and Sheikh and Wang (2012).

Foreign ownership is negatively related to debt ratio and statistically significant. This finding suggests that higher the foreign ownership in the firm lower will be the debt ratio of the firm. Thus foreign owners favor less debt and this is consistent with the pecking order theory in which the firm must finance its projects by internal sources. On the other hand, some studies also find a negative relationship between foreign ownership and capital structure like Svejnar\& Kocenda, (2002) Li et al. (2009) Lee and Kwok (1988) Mieno (2009) and Gurunlu, M., \& Gursoy (2010) finds that firms with high foreign investment in their equity have low gearing level because these companies mostly have high level of retained earnings to finance their projects internally. Previous studies like Gedajlovic et al. (2005) supported previous studies that there exist negative relationship between foreign ownership and capital structure. Tamimi (2011) conducted a study to find out the impact of foreign ownership on capital structure, the study finds a negative relationship between foreign ownership and capital structure. Institutional ownership is positively related to debt ratio and statistically significant. This finding suggests that higher the institutional ownership higher will be the debt ratio. This finding match with the previous studies like Bodaghi \& Ahmadpour (2010) study revealed that institutional ownership has positive relationship with capital structure which is consistent with corporate governance philosophy. Akbari \& Rahmani (2013) states that institutional shareholding helps the firm to raise external finance at favorable terms. Because these institution acts as the main source of external finance and in turn they enjoy the influence the company by entering in the board of that company. On the other hand, institutional investors also effectively monitor the strategic decision of the company and in turn reduce the agency problem and management opportunism. Institutional investor also boots up the confidence of other lenders and general public this leads to the reduction in cost of debt or raise debt on favorable terms.

Board size is positively related to debt ratio and statistically significant. This finding suggests that large board size favors higher debt ratio Large companies have large board size and such companies with giant assets take debt on favorable terms. Wen et al. (2002) concludes that size of board is positively related to capital structure. He says that high gearing level due to the large board size increases the firm's value. He also mentions that due to large board size, its member takes no early consensus on any decision which may affect the governance and ultimately results in high debt level. Large board size results in low debt cost because creditors think that the firm is under strict supervision of the diversified board. Coles et al. (2008) reports a positive relationship between board size and capital structure in American context. They provide a possible explanation for this is that firm with high gearing ratio may have larger advising requirements then firms with low gearing levels. Anderson et al. (2004) also found positive relationship between board size and debt ratio, he argues that firm with higher boards have easy access to debt at favorable terms. According to agency theory Jensen (1986) and Wen et al. (2002) reports positive relationship between board size gearing ratio. They argue that lager boards are more entrenched due to effective monitoring pursue higher gearing level to boost up the firm value. CEO duality is negatively related to debt ratio and statistically significant. This finding suggests that CEO duality leads to firm's lower debt usage. If CEO is also the chairman of the board lower will 
be the debt ratio of the firm. CEO duality in fact reduces separation of ownership and information asymmetry in the firm. According to Abor and Biekpe (2007) chair duality and composition of board is positively related to capital structure. Fosberg (2004) conducted a study to investigate the impact of corporate governance and capital structure; he found that CEO duality is positively related to gearing level. The author provides the explanation for this positive relationship is leadership duality lessens the problem of separation of ownership and control and therefore has high accessibility to the debt on favorable terms. Like the Fosberg (2004), Faleye (2007) also reports the positive relationship between CEO duality and capital structure, he provides the explanation for this relationship that Duality in leadership may lessens the problem of information asymmetry in turn this leads to higher access to external finance. A positive relationship between dual leadership and capital structure also reported by the Abor (2007). A possible explanation for relation in the context of Pakistan is that mostly firms are owned by families there also exist duality in leadership so they choose more debt financing over equity financing because they want to dilute their ownership. Board independence is positive related to debt ratio and statistically significant. This finding suggests that if board of the firm consists more number of outside and non-executive directors then higher will be the debt ratio or leverage of the firm. Higher the board independence higher the leverage of the firm. The creditors consider it credit worthy thus it makes easy for the firm to take debt from outsiders. Outside directors are the key part of the corporate governance.

According to Pfeffer and Salancick (1978) the presence of external directors on the board is much appreciated by the outsiders who have made their investments in the company. This makes the firm's images better in the eye of investors. Their study shows results that higher board independence increase leverage. Jensen (1986) and Berger et al (1997) found that high leverage is found in the firms which have high representation of non-executive directors and firms with low number of external directors have low debt level. According to Abor and Biekpe (2007) chair duality and composition of board is positively related to capital structure. Firm size is positively related to the leverage of the firm and has a significant positive impact on leverage. This means that larger the firm size higher will be the debt. Titman \& Wessels (1988) argued that big firms not consider the bankruptcy cost in deciding the level of leverage as these are just a small percentage of the total value of the firm so larger firms may prefer to use high level of leverage. Friend and Lang (1988), Marsh (1982) also find the positive relationship between firm size and gearing level. This study finds the profitability is negatively related to the gearing level of the firm. Myers \& Majluf (1984) argued that profitable firms have low level of leverage because they prefer to finance their projects by internally generated fund over debt. These findings are in line with the pecking order theory of capital structure. This study finds that Liquidity is negatively related to the leverage level of the firm. According to Al-Najjar, Taylor (2008) firms with more liquid assets may use their liquid assets as source of finance to fund future products and projects so that why there exist negative relationship. According to Myers \& Rajan (1998) there exist negative relationship between firm liquidity and gearing level. They explained this as the agency costs of liquidity increase outside creditors limit the amount of debt available to company. Firms with high liquidity use less level of external financing (Lingling, 2013).

\section{Conclusion}

The main objective of this study is to find out the impact of ownership structure and corporate governance on capital structure of the Pakistani listed firms. Capital structure pattern of the firm has been explained by several capital structure theories. Financial mix of the firm is the basic issue which is to be decided to increase the firm's value and performance by the managers. This decision is affected by different theories of capital structure. This study uses ownership structure and corporate governance variables to determine the financial mix of Pakistani firms. Ownership structure and corporate governance are used as independent variables and capital structure is used as dependent variable. A lot of work has done in the field of corporate governance but a small is found in the field of ownership structure. Thus present study focuses on both ownership structure and corporate governance practices. The capital structure of the firm is determined with ownership concentration, managerial ownership, foreign ownership, institutional ownership, board size, CEO duality and board independence. Different companies are characterized by different financial mix thus indicating different ownership and corporate governance practices. Different companies have different borrowing powers and control over the companies. Present study indicates that ownership structure and corporate governance have significant impact on capital structure of the firms and both are important in 
determining the financial mix of the firms. Managerial ownership is significantly negatively related to leverage indicating that there will be managerial opportunism in the firm. Managerial ownership is used as alternative to agency cost. Foreign ownership is negatively related to leverage which is consistent with the pecking order theory. In situations, the firms move from less risky to riskiest source of finance. Board size significantly positively related to leverage indicating that large firms having giant assets with large board size tend to take debt on favorable terms. CEO duality and leverage are negatively related showing that CEO also serving as chairman on the board leads to lower leverage. Board independence and leverage are positively related; this finding suggests that if board of the firm consists more number of outside and non-executive directors then higher will be the debt ratio or leverage of the firm. Higher the board independence higher the leverage of the firm. The creditors consider it credit worthy thus it makes easy for the firm to take debt from outsiders. Outside directors are the key part of the corporate governance. This study shows insignificant positive relationship of ownership concentration with the leverage indicating that firms with high ownership concentration tend to high financial leverage of the firm. In Pakistani companies most of the shares of the companies are held by family members and their relatives, so that they prefer debt financing over equity due to fear of the dilution of ownership and control (Hasan \& Butt, 2009).

\section{References}

A. S. Tamimi (2011) influence of foreign ownership on capital structure of None-Financial firms: Evidence form Amman Stock Exchange: faculty of graduate studies university of Jordan.

Abel, E. E \&Okafor, F. O. (2010). Local corporate ownership and capital structure decisions in Nigeria: A developing country perspective. Corporate Governance, 10(3), 249-260.

Abor, J. and N. Biekpe, 2007. Corporate governance, ownership structure and performance of SMEs in Ghana: Implications for financing opportunities. Corporate Governance, 7(3): 288-300.

Abor, J., 2007. Corporate governance and financing decisions of Ghanaian listed firms. Corporate Governance, 7(1): 83-92.

Adams, R. B., \& Mehran, H. (2012). Bank board structure and performance: Evidence for large bank holding companies. Journal of financial Intermediation, 21(2), 243-267.

Ahmad Ahmadpour, Ahmad Jafari Samimi and Hamze Golmohammadi, (2012) "Corporate Governance and Capital Structure: Evidence from Tehran Stock Exchange", Middle-East Journal of Scientific Research 11 (4): 531-535.

Ahmed Sheikh, N., \& Wang, Z. (2011). Determinants of capital structure: An empirical study of firms in manufacturing industry of Pakistan. Managerial Finance, 37(2), 117-133.

Akbari M \&Rahmani S (2013) Does corporate governance and ownership structure influence capital structure? Empirical evidence from Iran. World of science journal, 1(17), 72-85.

Al-Najjar, B., \& Taylor, P. (2008). The relationship between capital structure and ownership structure: New evidence from Jordanian panel data. Managerial Finance, 34(12), 919-933.

Anderson R., Mansi, S. and Reeb, D. (2004). Board Characteristics, Accounting Report Integrity and the Cost of Debt, Journal of Accounting and Economics, 37, 315-342.

Anderson, R. C. and Reeb, D. M. (2003). Founding-family ownership, corporate versification, and firm leverage, Journal of Law and Economics, 46(2): 653-680.

Arslan, M., Zaman, R., Malik, R. K. \& Mehmood, A. (2014). Impact of CEO Duality and

Audit Committee on Firm Performance: A Study of Oil \& Gas Listed Firms of Pakistan. Research Journal of Finance and Accounting, 5, 151-156.

Bajaj, M., Chan, Y. and Dasgupta, S. (1998), "The relationship between ownership, financing decisions and firm performance: a signaling model", International Economic Review, 39(3), 723-44.

Bear, S., Rahman, N., \& Post, C. (2010). The impact of board diversity and gender composition on corporate social responsibility and firm reputation. Journal of Business Ethics, 97(2), 207-221.

Bender, R. (2013). Corporate financial strategy. Routledge.

Berger, P.G., Ofek, E. and Yermack, D.L. (1997), "Managerial entrenchment and capital structure decisions", Journal of Finance, 52(4), 1411-38.

Bodaghi, A., \& Ahmadpour, A. (2010). The effect of corporate governance and ownership structure on capital structure of Iranian listed companies. 7th International Conference on Enterprise Systems, Accounting and Logistics (7th ICESAL 2010) 28-29 June 2010, Rhodes Island, Greece, 89-96. [Online] Available: http://www.icesal.org/2010\%20PROCEEDINGS/docs/P8.pdf (April 22, 2012). 
Bokpin, G. A., \& Arko, A. C. (2009). Ownership structure, corporate governance and capital structure decisions of firms: Empirical evidence from Ghana. Studies in Economics and Finance, 26(4), 246-256.

Brailsford, T. J., Oliver, B. R., \& Pua, S. L. (2002). On the relation between ownership structure and capital structure. Accounting \& Finance, 42(1), 1-26.

Cadbury, A 1992, 'The financial aspects of corporate governance', the final report of the Committee on the Financial Aspects of Corporate Governance, viewed on 8 June 2013 www.ecgi.org

Cheema, A., F. Bari and O. Saddique, (2003). Corporate governance in Pakistan: Ownership, control and the law. Lahore: Lahore University of Management Sciences.

Cheng, S. (2008). Board size and the variability of corporate performance. Journal of financial economics, 87(1), 157-176.

Cheng, S., Nagar, V. and Rajan, M. (2005), "Identifying control motives in managerial ownership: evidence from antitakeover legislation", Review of Financial Studies, 18, 636-72.

Coles, J. L., Daniel, N. D., \& Naveen, L. (2008). Boards: Does one size fit all? Journal of financial economics, 87(2), 329-356.

Driffield, N., Vidya, M. and Sarmistha, P. (2005), "How ownership structure affects capital structure and firm performance? Recent evidence from East Asia", Finance 0505010, Economics Working Paper Archive EconWPA.

Erickson, J., Park, Y. W., Reising, J., \& Shin, H. H. (2005). Board composition and firm value under concentrated ownership: The Canadian evidence. Pacific-Basin Finance Journal, 13(4), 387-410.

Faleye, O. (2007). Classified boards, firm value, and managerial entrenchment. Journal of Financial Economics, 83(2), 501-529.

Fosberg, R.H (2004, 'Agency problems and debt financing: Leadership structure effects', Corporate Governance, 4(1), 31-38.

Friend, I., \& Lang, L. H. P. (1988). An empirical test of the impact of managerial self-interest on corporate capital structure. The Journal of Finance, 43(2), 271 -281.

Gedajlovic, Eric, Yoshikawa, Toru and Hashimoto, Motomi (2005) Ownership structure, investment behavior and firm performance in Japanese manufacturing industries. Research Collection Lee Kong Chian School of Business, Paper 2288.

Grier, P., \& Zychowicz, E. J. (1994). Institutional investors, corporate discipline, and the role of debt. Journal of Economics and Business, 46(1), 1-11.

Gurunlu, M., \& Gursoy, G. (2010). The influence of foreign ownership on capital structure of non-financial firms: evidence from Istanbul Stock Exchange. IUP Journal of Corporate Governance, 9(4), 21.

Hasan, A., \& Butt, S. A. (2009). Impact of ownership structure and corporate governance on capital structure of Pakistani listed companies. International Journal of Business and Management, 4(2), 50-57

http://www.adb.org/countries/pakistan/economy

Huang, G. and Song, F.M., (2006). The determinants of capital structure: Evidence from China. China Economic Review, 17, 14-36.

Jabbarzadeh Kangarlouei, S., Kavasi, B., \& Motavassel, M. (2013). The effects of outside board on firm value in Tehran Stock Exchange from the perspective of information transaction costs. International Journal of Industrial Mathematics, 5(4), 375-386.

Jensen, M (1986), 'Agency cost of free cash flow, corporate finance and takeovers', American Economic Review Papers and Proceedings, 76, 323-329.

Jensen, M. and Meckling, W.H. (1976) 'Theory of the firm: managerial behavior, agency costs and ownership structure', Journal of Financial Economics, 3: 305-360.

Jensen, M. C. (1986). Agency Costs of Free Cash Flow, Corporate Finance and Takeovers. American Economic Review, 76, 323-329

Johnson, S., La Porta, R., Lopez-De-Silanes, F., \&Shleifer, A. (2000). Tunneling. The American Economic Review, 90(2), 22-27.

Koch, P.D. and Shenoy, C. (1999), "The information content of dividend and capital structure policies", Financial Management, 28(4), 16-35.

Kumar, N., \& Singh, J. P. (2013). Effect of board size and promoter ownership on firm value: some empirical findings from India. Corporate Governance: The international journal of business in society, 13(1), 8898. 
Lee, Kwang and Kwok, Chuck (1988) Multinational corporations vs. domestic corporations: international environmental factors and determinants of capital structure. Journal of International Business Studies, 19 (2): 195-217.

Li, K., Yue, H., \& Zhao, L. (2009). Ownership, institution, and capital structure: evidence from China. Journal of Comparative Economics, 37, 471 -490.

Lingling Z. (2013) the impact of ownership structure on capital structure; Evidence from listed firms in China. School of management and governance financial management, University of Twente, Netherlands.

Maddala, C.S. and Mount, T.D. (1973) "A Comparative Study of Alternative Estimators for Variance Components Models Used in Econometric Applications". Journal of the American Statistical Association, 68: 324-328.

Mak, Y. T., \& Kusnadi, Y. (2005). Size really matters: Further evidence on the negative relationship between board size and firm value. Pacific-Basin Finance Journal, 13(3), 301-318.

Masood, A., \& Shah, A. (2014). Corporate governance and cash holdings in listed non-financial firms of Pakistan.

Mieno, Fumiharu (2009) Foreign ownership, listed status, and the financial system in East Asia: Evidence from Thailand and Malaysia. Asia-Pacific Economic Cooperation Discussion Paper Seriesno.64, Columbia University, New York, United States.

Mishra, C.S. and McConaughy, D.L. (1999), "Founding family control and capital structure: the risk of loss of control and the aversion to debt", Entrepreneurial Theory and Practice, 23(4), 53-64.

Modigliani, F. and Miller, M. (1958), "the Cost of Capital, Corporation Finance and the Theory of Finance' 'American Economic Review, 48(1), 261-97.

Mohid, M. A., Perry, L. G., \& Rimbey, J. N. (1998). The impact of ownership structure on corporate debt policy: a time-series cross-sectional analysis. The Financial Review, 33, 85-98.

Myers, S. C. (2001). Capital Structure, The Journal of Economic Perspectives, 15(2), 81-102

Myers, S. C., \& Rajan, R. G. (1998). The paradox of liquidity. The Quarterly Journal of Economics, 113(3), 733771.

Myers, S., and N. Majluf. (1984). Corporate Financing and Investment Decisions When Firms Have

Information Investors Do Not Have. Journal of Financial Economics, 13, 187-222.

N. H. Wellalage and S. Locke, (2014), "Impact of ownership structure on capital structure of New Zealand unlisted firms. Journal of Small Business and Enterprise Development, 22(1), 127-142.

O'Connell, V., \& Cramer, N. (2010). The relationship between firm performance and board characteristics in Ireland. European Management Journal, 28(5), 387-399.

Pakistan institute of corporate governance 2011, 'Survey on Board Practices in Pakistan', viewed on June 2013, www.picg.org.pk

Pfeffer, J. and Salanick, G.R. (1978), The External Control of Organizations: A Resource Dependence Perspective, Harper \& Row, New York, NY.

Pindado, J., \& La Torre, D. C. (2011). Capital structure: new evidence from the ownership structure. International Review of Finance, 11(2), 213-226.

Rajangam, N., Sundarasen, S. and Rajajopalan, U. (2014) Impact of Governance on Profitability and Gearing of Companies, Asian Social Science, 10(10), 13-23.

Ryen, G.T., Vasconcellos, G.M. and Kish, R.J. (1997), “Capital structure decisions: what have we learned?", Business Horizon, 40(5) 41-50.

Saeedi, A \& Mahmoodi I, (2011), Capital Structure and Firm Performance: Evidence from Iranian Companies, International Research Journal of Finance and Economics, 70: 21-28.

Salim, M., \& Yadav, R. (2012). Capital Structure and Firm Performance: Evidence from Malaysian Listed Companies. Procedia - Social and Behavioral Sciences, 65 (ICIBSoS), 156-166. doi: 10.1016/j.sbspro.2012.11.105

Securities and Exchange Commission of Pakistan (2012), 'The codes of corporate governance report', viewed on 19 June 2013, www.secp.gov.pk

Sheikh, N. A. and Wang, Z. (2012), "Effects of corporate governance on capital structure: empirical evidence from Pakistan", Corporate Governance: The international journal of business in society, 12(5), 629 641.

Shleifer, A, \& Vishny, R, W (1997). 'A survey of corporate governance', The Journal of Finance, 52(2), 737-783.

Short, H., Keasey, K., \& Duxbury, D. (2002). Capital structure, management ownership and large external shareholders: a UK analysis. International Journal of the Economics of Business, 9(3), 375-399. 
Svejnar, J., \& Kocenda, E. (2002). The effects of ownership forms and concentration on firm performance after large-scale privatization.

Titman, S., \&Wessels, R. (1988). The determinants of capital structure choice. The Journal of Finance, 43(1), 1 19.

Ukaegbu, B. (2014). The significance of working capital management in determining firm profitability: Evidence from developing economies in Africa. Research in International Business and Finance, 31, 1-16.

Wen Y, Rwegasira, K, \& Bilderbeek, J (2002) 'Corporate governance and capital structure decisions of the Chinese listed firms', Corporate Governance: An International Review, 10(2), 75-83.

Yan Lam, T., \& Kam Lee, S. (2008). CEO duality and firm performance: evidence from Hong Kong. Corporate Governance: The international journal of business in society, 8(3), 299-316.

Zeitun, R., Tian, G. (2007). Capital structure and corporate performance: evidence from Jordan, Australasian Accounting Business and Finance Journal, 1: 40-53.

Zheka, V. (2005), "Corporate governance, ownership structure and corporate efficiency: the case of Ukraine", Managerial and Decision Economics, 26(7), 451-60.

$\begin{array}{ll}\text { Abbreviations } & \\ \text { CG } & \text { Corporate Governance } \\ \text { GLS } & \text { Generalized Least Square } \\ \text { FGLS } & \text { Feasible Generalized Least Square } \\ \text { KSE } & \text { Karachi Stock Exchange } \\ \text { PSE } & \text { Pakistan Stock Exchange } \\ \text { ICAP } & \text { Institute of Chartered Accountant of Pakistan } \\ \text { PICG } & \text { Pakistan Institute of Corporate Governance } \\ \text { SECP } & \text { Security \& Exchange Commission of Pakistan } \\ \text { SBP } & \text { State Bank of Pakistan }\end{array}$

